\title{
Distribution, epidemiological characteristics and control methods of the pathogen Nosema ceranae Fries in honey bees Apis mellifera L. (Hymenoptera, Apidae)
}

\author{
Distribución, características epidemiológicas y métodos de control del patógeno \\ Nosema ceranae Fries en abejas Apis mellifera L. (Hymenoptera, Apidae) \\ X Araneda ${ }^{a^{*}}$, M Cumian $^{\mathbf{b}}$, D Morales ${ }^{\mathrm{a}}$ \\ aAgronomy School, Natural Resources Faculty, Universidad Católica de Temuco, Temuco, Chile. \\ ${ }^{\mathrm{b}}$ Agriculture and Livestock Service (SAG), Coyhaique, Chile.
}

\begin{abstract}
RESUMEN
El parásito microsporidio Nosema ceranae, hasta hace algunos años fue considerado como patógeno de Apis cerana solamente, sin embargo en el último tiempo se ha demostrado que puede afectar con gran virulencia a Apis mellifera. Por esta razón, ha sido denunciado como un agente patógeno activo en la desaparición de las colonias de abejas en el mundo, infectando a todos los miembros de la colonia. Es importante mencionar que las abejas son ampliamente utilizadas para la polinización y la producción de miel, de ahí su importancia en la agricultura, además de desempeñar un papel ecológico importante en la polinización de las plantas donde un tercio de los cultivos de alimentos son polinizados por abejas, al igual que muchas plantas consumidas por animales. En este contexto, esta revisión pretende resumir la información generada por diferentes autores con relación a distribución geográfica, características morfológicas y genéticas, sintomatología y métodos de control que se realizan en aquellos países donde está presente $N$. ceranae, de manera de tener mayores herramientas para enfrentar la lucha contra esta nueva enfermedad apícola.
\end{abstract}

Palabras clave: parásito, microsporidio, Apis mellifera, Nosema ceranae.

\section{SUMMARY}

Up until a few years ago, the microsporidian parasite Nosema ceranae was considered to be a pathogen of Apis cerana exclusively; however, only recently it has shown to be very virulent to Apis mellifera. Therefore, it has been named as apathogenic agent active in the disappearance of honey bee colonies globally, infecting all members of the colony. Honey bees are widely used for pollination and honey production, hence their importance in agriculture. They also play an important ecological role in plant pollination: a third of human food crops are pollinated by bees as well as many plants consumed by other animals. In this context, the object of this review is to summarise the information published by different authors on the geographical distribution and the morphological and genetic characteristics of this parasite, the symptomatology of the disease and the control methods used in those countries where $N$. ceranae is present, in order to identify better tools to confront this new bee disease.

Key words: parasite, microsporidian, Apis mellifera, Nosema ceranae.

\section{INTRODUCTION}

Honey production has become an important feature of world agriculture, since the bees that produce it play a role in pollination and food production (Bradbear 2009). In recent years there has been a reduction in populations of Apis mellifera L. (Hymenoptera, Apidae) in Northern Hemisphere countries (Potts et al 2010, vanEngelsdorp et al 2010).

According to Ellis et al (2010), the cause of this depopulation and the eventual disappearance of colonies is not yet clear. Honey bee populations have been declining steadily since 1940 and the consensus of researchers indicates that parasites are an important factor in this disappearance. One such parasite is Nosema ceranae Fries, and perhaps the most recent and virulent (Martin-Hernández et al 2007,

Accepted: 27.11.2014.

* PO Box 15-D, fax: 045-2205540, Temuco, Chile; xaraneda@uct.cl
Gisder et al 2010). The credibility of this theory is based on the fact that all parasites are dependent on the energy from their hosts to reproduce, causing them significant nutritional stress and eventually, death (Mayack and Naug 2009).

Nosema spp. are single-celled parasites belonging to the phylum Microspora. They are characterised by the production of a resistant spore containing a polar filament, which transmits genetic material into the host cell (Wittner and Weiss 1999). Infection ranges from the most common chronic form to the less frequent acute form of the disease. The genus Nosema, which belongs to the class Microsporidia, contains more than 150 species, these can infect invertebrate hosts including at least 12 orders of insects (Higes et al 2007). The parasite $N$. ceranae is one species of the genus, infecting the Asian bee Apis cerana Fabricius and the european bee A. mellifera (Fries et al 1996, Higes et al 2006). In addition Nosema spp. are commonly found in Lepidoptera and Hymenoptera, 
causing them diseases such as silkworm pebrine, caused by Nosema bombycis Nägeli and bee dysentery, caused by Nosema apis Zander (Higes et al 2007).

Until recently $N$. apis was thought to be the only cause of nosemosis in the european bee A. mellifera, whilst $N$. ceranae had only been detected in oriental bees $A$. cerana. However, recent studies have shown that $N$. ceranae has changed its feeding habits and is no longer unique to the eastern bee, but has also become a very efficient parasite of european bees (Higes et al 2007, Chen et al 2008, Chen et al 2009a, Chen et al 2009 ) and several species of bumblebees (Plischuk et al 2009, Li et al 2012, Graystock et al 2013). The resulting disease is known as type $\mathrm{C}$ nosemosis (Higes et al 2010 ${ }^{\mathrm{b}}$ ).

Initial investigations were focused on finding the differences and similarities that exist between these microsporidia, the first conclusion being that both directed their attack at the epithelium of the ventricle (Higes et al 2007). The disease can infect all members of the colony including worker bees, drones and queens. Traver and Fell (2011) point out that drones could be important agents in the spread of this disease between apiaries. According to Alaux et al (2011), the effect of $N$. ceranae on queens could result in changes to the production of pheromones, which may explain their replacement. Another similarity is that Nosema infection occurs mainly by the ingestion of spores through food and water. They breed in the mid-intestine of the honey bee and the spores are finally eliminated in the faeces, providing new sources of infection through cleaning and feeding activities within the colony (Chen et al 2009a).

The symptoms of honey bee nosemosis caused by $N$. apis are easier to observe; there are large numbers of dead bees in the colony and diarrhoea stains at hive entrances, indicating digestive system disorders (Bourgeois et al 2010). However, this is regarded as a fairly benign pathogen that rarely causes colony losses (Bailey 1967, Bailey and Ball 1991). By contrast, the symptoms of infection by N. ceranae are less obvious; colonies grow weaker (Bourgeois et al 2010) and it is possible to detect the disease throughout the entire year (Higes et al 2010 b). Moreover, it has been identified as the main causative agent for the loss of colonies in many geographical regions (Martin-Hernandez et al 2007, Higes et al 2008), suggesting that $N$. ceranae is more virulent than $N$. apis (Higes et al 2007). It may be added that infestation by any type of Nosema will result in a decline in honey production and foraging activity, and therefore a decline in pollination (Bourgeois et al 2010).

According to Paxton (2010), N. ceranae is an emerging, potentially virulent pathogen which has spread throughout the world in the past 10 years, which explains why researchers have detected it in both healthy and weak honey bee colonies (Martin-Hernández et al 2007, Chen et al 2008, Higes et al 2008).

The object of this review is to summarise the information available in various scientific publications to document biological characteristics of the pathogen: its geographical distribution, the symptomatology of the disease, and control strategies, in order to systematize new background material in the fight against this dangerous pathogen of the european honey bee $A$. mellifera.

\section{DISCOVERY AND GEOGRAPHICAL DISTRIBUTION}

In $1994 N$. ceranae was detected for the first time in Beijing (China) in Asian bees (A. cerana) (Fries et al 1996). Later Higes et al (2006) reported the presence of $N$. ceranae infecting A. mellifera in Europe for the first time.

Chen et al (2008) collected samples of honey bees between the years 1995 to 2007 and found the pathogen in 12 states in the USA; Liu et al (2008) reported it in China, while other reports over the years include Canada (Williams et al 2008a); Greece (Bacandritsos et al 2010); Thailand (Chaimanee et al 2010); different prefectures in Japan (Yoshiyama and Kimura 2011); several Balkan countries (Stevanovic et al 2011); and Turkey (Whitaker et al 2011). Moreover, Klee et al (2007) reported that $N$. ceranae is a disease of global proportions detected in many parts of the world, including Europe, Africa, Asia, America and Oceania (Higes et al 2006, Calderón et al 2008, Giersch et al 2009, Higes et al 2009º, Chen and Huang 2010). In South America, studies have confirmed the presence of N. ceranae in Brazil (Texeira et al 2013), Uruguay (Invernizzi et al 2009), Argentina (Plischuk et al 2009, Medici et al 2012) and Chile (Martínez et al 2012, Rodríguez et al 2012).

Martin-Hernández et al (2007) indicate that colonies exposed to $N$. ceranae have a depopulation risk almost six times greater than those without $N$. ceranae. In this context Higes et al $\left(2007,2008,2010^{c}\right)$ and Chen et al (2008) suggest that $N$. ceranae can cause the sudden collapse of bee colonies, causing important diseases at an individual level (Chen and Huang 2010, Dussaubat et al 2012). N. ceranae also has an impact at the honey bee colony level (not only the collapse of the colony), for example the decrease in adult bee population and honey production (Higes et al 2008, Botias et al 2013). Subsequently, Paxton (2010) suggests that it may act not only as a single cause, but possibly also in combination with other factors such as loss of habitat and floral resources, which has clearly aroused the curiosity of beekeepers and the scientific world.

Nevertheless, although the presence of $N$. ceranae in Brazil was confirmed in 2006, it has been affecting Africanised bees for at least 34 years. Its presence was detected recently in Uruguay, although it has not yet caused particular damage in that area and its impact is still unclear (Invernizzi et al 2009, Texeira et al 2013), probably due to the presence of a less virulent strain of the parasite or a resistant feature in the bees (Higes et al 2008, Vandame and Palacio 2010). It is therefore suggested that the parasite is more pathogenic in Europe than in North America (Higes et al 2008, van Engelsdorp 
et al 2009), making it difficult to assess the real mortality in western colonies (Williams et al 2010). Furthermore, tests carried out in Spain indicated that both N. ceranae and $N$. apis may be present in hives without causing symptoms of the disease, and that there is no evidence of the replacement of $N$. apis by $N$. ceranae, suggesting that nosemosis is not the principal cause of hive collapse and death (Fernández et al 2012).

\section{Nosema ceranae IN CHILE}

In Chile, nosemosis has been reported in hives in the Libertador General Bernardo O'Higgins District, caused mainly by $N$. apis, with greater prevalence during the spring due to high fecal contamination in colonies at the end of winter (Hinojosa and Gonzalez 2004). Nosema has been detected in $10 \%$ of colonies in the Azapa valley, Arica and Parinacota Districts (Huaiquil et al 2009). Although there is little information on the presence of $N$. ceranae in Chile, in 2009 the Agriculture and Livestock Service (SAG) officially confirmed the presence of $N$. ceranae in apiaries in the Biobio Region (Fuentealba and Linero 2010). During early spring 2010, beekeepers with apiaries in Curepto, Maule District (3459.986'S, $71^{\circ} 53.377^{\prime} \mathrm{W}$ ), reported mass deaths of bees in which $52 \%$ of the samples analyzed were infected with $N$. ceranae (Rodríguez et al 2012). During the 2010-2011 season Martinez et al (2012) examined 240 hives in the Biobio District in southern Chile and detected $N$. ceranae positive samples in $49 \%$ of these. The level of infection ranged from 200 to more than 100,000 spores per bee. Meanwhile, Rodríguez et al (2014) detected N. ceranae in 18\% of hives analysed in the Biobío District out of a total of 180 colonies sampled. It is suggested that $N$. ceranae may be the real cause of nosemosis in A. mellifera in South America.

\section{MORPHOLOGICAL FEATURES}

Microsporidia are a group of single-celled fungi that infect a wide variety of animals including honey bees. They are also known for their simple genome and cell features, a result of their adaptation to obligate intracellular parasitism (Corradi and Slamovits 2010).

Chen et al (2009a) report that under the optical microscope fresh spores of $N$. ceranae are ovoid, oval or cylindrical in shape, straight or slightly curved, varying from 3.9 to $5.3 \mu \mathrm{m}$ and from 2.0 to $2.5 \mu \mathrm{m}$ width. Fries et al (1996) reported that they measure $4.7 \times 2.7 \mu \mathrm{m}$ fresh, and $3.6 \times 2.7 \mu \mathrm{m}$ when fixed and stained. The proteins observed in the vacuole and vesicle in $N$. ceranae are absent in $N$. apis, suggesting that species-specific genes are involved in the structure and function of cell components (Chen et al 2013).

In addition, $N$. ceranae spores contain a polar filament, diameter 96-102 nm, with between 18 and 21 coils (Fries et al 1996, Chen et al 2009a). The parasite is characterised by the expulsion of the polar filament from the spore in the presence of potential host cells in the surrounding area, using this mechanism to penetrate the cell membrane of the host. Subsequently, rapid swelling of the vacuole located in the back of the spore exerts strong pressure on the cell contents, pushing them through the polar tube. Successful propagation is followed by lysis of the host cell and spore release (Corradi and Slamovits 2010)

According to Gisder et al (2010), the intracellular life cycle is divided into two phases: the proliferation phase, called merogony, and the multiplication phase, which finishes with spore formation, called sporogony. Once the filament penetrates the cell, sporoplasm is injected and multiplies in the cytoplasm of the host cell. At this stage the spore injected from the mother spore develops through four distinguishable forms. These forms are schizonts, sporonts, sporoblasts and mature spores, which will eventually be released into the environment to attack another cell (Chen et al 2009ª , Gisder et al 2010).

\section{GENETIC FEATURES}

Chen et al $\left(2009^{\mathrm{a}}\right)$ conducted a parallel comparison of the rRNA gene sequences of $N$. ceranae and $N$. apis, and found that although they infect the same host and share similarities in their rRNA gene sequences $N$. apis is not the closest relative to $N$. ceranae; $N$. ceranae appears to be more closely related to Nosema vespula, a parasite in the same clade that infects wasps, while $N$. apis seems to have developed earlier and is more closely linked to $N$. bombi, a parasite infecting bumble bees.

However, Shafer et al (2009) used multiple data sequences to compile the phylogeny of microsporidia affecting bees and came to the conclusion that $N$. ceranae is a sister species of Nosema bombi Fantham \& Porter while $N$. apis is the basal member of the clade. Nevertheless, it is suggested that future attempts to study the phylogeny of $N$. ceranae will require the development of markers with one polymorphic locus only (O'Mahony et al 2007). These will also be reliable, since Chen et al (2013), using specific primers for $N$. apis, successfully confirmed the specificity of the species by amplifying the fragment sequence using PCR, while the same primers did not generate any PCR product in $N$. ceranae. In view of this, Gisder and Genersch (2013) presented a reliable new protocol to discriminate between $N$. apis and $N$. ceranae, based on amplification of sequences of the largest subunit (RPB1) of RNA polymerase II, using species-specific primers. This proved more reliable than the widely used gene-based 16S rRNA protocols that have been used for the comparison. When both species are present in the same host, Carletto et al (2013) suggest that the PCR multiplex kit could detect small numbers of one species of Nosema when larger numbers of the other are also present. This confirms that the PCR technique in a single, multiplexed, real time reaction facilitates 
the detection and quantification of both $N$. apis and $N$. ceranae, making it a useful technique for diagnosing diseases such as nosemosis (Bourgeois et al 2010).

Furthermore, high levels of genetic diversity have been observed in isolations, evidence of meiotic recombination in populations of $N$. ceranae, without signs of differentiation between populations from different locations (Van der Zee et al 2014).

Another important aspect of $N$. ceranae is the high level of intraspecific polymorphism (due to the high nucleotide diversity and allele content of all its genes), not only within the species, but also within individual samples, as well as the coexistence of a broad variety of haplotypes within each bee colony and the occurrence of genetic recombination in the RPB1 locus. The latter has led to the recent population expansion of the parasite, due to the presence of multiple haplotypes in individual isolations (Roudel et al 2013, Gómez-Moracho et al 2014). Differences in virulence have been reported in the different genes due to increased genetic diversity, resulting from variations generated by intragenomic and/or intergenomic recombination between the sequences (Ironside 2013). This suggests a high degree of heterogeneity between the strains of $N$. ceranae infecting the individual colonies (Whitaker et al 2011, Van der Zee et al 2014), and this variation may be related to the entry of microsporidia at different points in the country, causing the variable symptomatology found in the field. It is therefore necessary to evaluate the current protocols for the recognition of this parasite as the principal agent causing nosemosis (Medici et al 2012), since proofs of gene recombination suggest that this species may effect hidden sexual reproduction. This possibility has profound implications for the evolution of the virulence of the species, the range of possible hosts, and its resistance to treatment (Ironside 2013).

\section{DAMAGE FEATURES}

The characteristics of this disease are the inexplicable disappearance of adult honey bees, lack of attention to the offspring, a reduction in the vigor of the colony, and high winter mortality without prior pathological changes (Higes et al 2009ª). Martin-Hernández et al (2007) say that it is a clear sign of weakness in a colony when the queen cannot replace the loss of infected bees. In fact, the risk of depopulation of a colony is six times higher in colonies infected with $N$. ceranae than in those not infected.

Higes et al $\left(2010^{\mathrm{a}}\right)$ studied the biotic potential of $N$. apis and $N$. ceranae at a temperature of $33^{\circ} \mathrm{C}$, recording a similar result in both cases; however, when measured at extreme values of between $25^{\circ} \mathrm{C}$ and $37^{\circ} \mathrm{C}$, the biotic potential of $N$. ceranae was higher than that of $N$. apis, meaning that it will cause greater problems for beekeepers in summer months and in warm climates (Bourgeois et al 2010). This is due to the presence of proteins involved in the response to stress and endogenous stimuli that are more representative in $N$. ceranae than $N$. apis, suggesting that $N$. ceranae could have a greater ability to survive under stress conditions (Chen et al 2013).

Chen et al $\left(2009^{b}\right)$ studied the coexistence of $N$. ceranae with $N$. apis and found that bees captured in the United States and Asia were $31 \%$ positive for $N$. apis and $71 \%$ positive for $N$. ceranae, whilst $19 \%$ presented both infections. The authors therefore suggest that $N$. ceranae has better mechanisms for coping with honey bee immunity and reproduces faster than $N$. apis. However, the differences in response to bee infection are more likely to be related to the degree of tolerance to $N$. ceranae of each honey bee subspecies or of the local hybrids, or even to experimental conditions in the case of laboratory tests, than to differences between $N$. ceranae isolates (Dussaubat et al 2013 ${ }^{\mathrm{b}}$ ). Furthermore, infection with $N$. ceranae weakens the chemical mechanisms that regulate behavior maturation, especially the balance between nurses and foragers, which in turn has an impact on colony homeostasis. This makes colonies more susceptible to other environmental stress factors (Dussaubat et al 2013 ${ }^{\mathrm{a}}$ ), since the impact on colony homeostasis is a consequence of the former effects.

It is characteristic of the disease that the parasite attacks the epithelial cells of the ventricle, causing cell degeneration and subsequent rupture of cell membranes; this leaves the intestine edematous and friable (Higes et al 2007, 2009a). Infected cells present an elongated appearance with apical displacement of the nucleus. The cytoplasm contains a greater number of mitochondria and shows evidence of degeneration such as the presence of vacuoles and lysosomes, the majority of which are secondary and irregular in shape with heterogeneous electrodense areas (Dussaubat et al 2013 ${ }^{\mathrm{b}}$ ). Chen et al $\left(2009^{\mathrm{a}}\right.$ ) performed PCR tests on specific nucleic acids, indicating that $N$. ceranae is detected in $100 \%$ of alimentary canals, malpighian tubes, and hypopharyngeal glands; $87 \%$ of salivary glands; and $20 \%$ of fat bodies. However, these results have not been confirmed by histopathological studies, and nor have different developmental stages of Nosema been observed in cell types other than the epithelial cells of the ventriculum. The latter are not a primary target for infection by $N$. ceranae, although body fat is one of the primary infection sites for these microsporidia which also infect muscle tissue. With regard to the mode of transmission, Smith (2012) suggests that the spores of $N$. ceranae can be transmitted orally, which may explain its rapid spread as the food produced by the colony is shared by its members.

Turning to the time which elapses from ingestion to infection, only a few epithelial cells of the ventricle are infected by day three, while the majority of cells are infected after day seven. It is at this point that evidence of degeneration appears, with a mortality rate of $66.7 \%$ on the sixth day, $94.1 \%$ on the seventh day and $100 \%$ on the eighth day (Higes et al 2007). Vidau et al (2011) on the other hand reported maximum mortality 20 days 
after infection (47\%). Higes et al (2013) indicate that the cause of these mortalities is the fact that $N$. ceranae prevents apoptosis in the epithelial cells of the infected ventricle. This may be a mechanism designed to improve the development of the parasite.

One of the most serious problems with this disease arises from the fact that it destroys the intestine of the bee. As a consequence of the damage to their epithelial cells, the bees necessarily suffer energy stress (Alaux et al 2010), since the microsporidia use their remaining mitochondrial organelles to absorb the ATP of the host cell environment (Williams 2009). For this reason, honey bees affected by $N$. ceranae consume more food to meet their increased energy demand (Alaux et al 2010); because they are hungrier they are also more reluctant to share food, thus reducing the connectivity of the network within the colony (Naug and Gibbs 2009). In addition, there is significantly less trehalose in the hemolymph of foraging honey bees infected with $N$. ceranae than in uninfected foragers. This affects the bee's flying ability and may cause it to abandon its social conditioning in order to meet its individual food needs, despite the social signals imposed by hives, such as the demand for nectar (Mayack and Naug 2010). This results in some heavily infected honey bees (generally foragers) not returning to the hive (Higes et al 2009 ), due to the potential of increased flying activity by infected bees to reduce the transmission of the pathogen within the hive (Dussaubat et al 2013 ${ }^{\text {a }}$.

Furthermore Antunez et al (2009) and Genersch (2010) report that infection by $N$. ceranae seems to suppress the immune response, by reducing the transcription of some genes that encode antimicrobial peptides and other immunity-related enzymes, in contrast to infection by $N$. apis where the immune system is quickly activated. A dramatic effect of microsporidia infection is the inhibition of genes involved in homeostasis and the renewal of intestinal tissues, confirmed at a histological level, which would explain the early death of the bees due to tissue degeneration and prevention of the renewal of the intestinal epithelium (Dussaubat et al 2012).

Antunez et al (2009) indicated that the expression of the antibacterial peptides abaecin, denfesin and hymenoptaecin increases four days after infection with $N$. apis. On the other hand, the infection caused by $N$. ceranae did not affect the expression of antibacterial peptides, despite the fact that the pathogen had already invaded the ventricular epithelium (Higes et al 2007). This suggests that $N$. ceranae partially suppresses the humoral and cellular defense mechanisms, thus increasing susceptibility to other bee pathogens and also anticipating senescence (Antunez et al 2009).

Alaux et al (2010) indicate that the interaction between infection with $N$. ceranae and exposure to pesticides causes a decrease in the secretion of antiseptics for the young, which affects their survival.

In addition to the damage caused to the bee intestine, there is stress due to lack of energy and the reduction in immunological capacity, the picture is further complicated if the disease affects the queen. The queen bee is susceptible to most of the diseases that affect the colony (Higes et al $\left.2009^{c}\right)$. Alaux et al (2011) studied this change in the behaviour of the pheromones of the queen, indicating that it significantly reduces her level of vitellogenin, an indicator of longevity and fertility. In addition, the queen's total antioxidant capacity and production of mandibular pheromone decreases, indicating that she cannot withstand the physiological stress caused by $N$. ceranae in the long term. Death occurs usually in the winter months when there is more contact between the sick workers and the queen, as compared to spring when there is a greater presence of uninfected young workers and more movement in the colony. Death of the queen occurred within three weeks in an experiment in which nurse honey bees were collectively infected with approximately 5,000 viable spores per bee (Higes et al 2009c). Production of N. ceranae spores presents a linear increase from 12 to 20 days after inoculation, with growth rates of $8 \times 10^{6}$ spores per day (Huang and Solter 2013).

It has been shown that sub-lethal doses of insecticides may increase mortality in bees previously infected by $N$. ceranae, making the bees more susceptible to the insecticides (Vidau et al 2011).

Regarding the application of insecticide treatments and the exposure of honey bees to $N$. ceranae, both these stress factors cause a significant reduction in survival when compared to healthy bees with no exposure to fipronil, for example (Aufauvre et al 2014). The interaction of parasites and insecticides added to other stress factors may have negative synergistic effect on bee survival, contributing to increased colony loss (Aufauvre et al 2012, Retschnig et al 2014). A synergetic effect has also been observed on the mortality of honey bees co-exposed to spores of Nosema spp. and to imidacloprid (Alaux et al 2010). Likewise the combination of $N$. ceranae and fipronil has led to a synergetic effect on mortality in honey bees, independent of the order of exposure to the stress factors (Vidau et al 2011, Aufauvre et al 2012).

Pesticides can also act on the insects' immunological systems (Desneux et al 2007, Garrido et al 2013). For example, fungicides, acaricides, neonicotinoids and phenylpyrazoles alter the bee's immune response, affecting the regulation of immune genes and leading to significant over-expression of a chitinase-encoding gene in bees exposed to N. ceranae (Boncristiani et al 2012, Garrido et al 2013, Aufauvre et al 2014).

It has further been shown that co-infection with Nosema specifically alters the nutritional, metabolic and hormonal pathways, including the insulin signalling pathway. The latter is also linked to maturation behaviour in workers, affecting the foraging tasks of infected individuals, similar to the results found in workers fed with poor diets (Holt et al 2013). This shows the importance of nutrition in optimising immunity (Ponton et al 2011), since poor 
nutritional states affect the immunological system (Holt et al 2013). For this reason early feeding of colonies infected with Nosema may help them to overcome the additional energy costs (Higes et al $2010^{\mathrm{b}}$ ).

\section{CONTROL METHODS}

When the bees cannot themselves control the attack of a parasite, it is necessary to find some alternative method to reduce the damage caused by the disease, such as pharmacological treatments. However, until more research on the biology and the transmission of $N$. ceranae becomes available, it is difficult to say whether the general recommendations for $N$. apis are relevant for the control of $N$. ceranae (e.g. wax replacement, fumigation of the comb with acetic acid) (Manzoor et al 2013). Currenty, science is focused on discovering new drugs. Williams et al $\left(2008^{\mathrm{b}}\right)$ studied the use of Fumagillin for controlling $N$. ceranae, finding that the use of this drug in the autumn succeeds in reducing the intensity of the parasitic invasion in the following spring. Fumagillin treatment is therefore shown to be successful in temporarily reducing $N$. ceranae infection in colonies (Botias et al 2013). However, Williams et al $\left(2008^{b}\right)$ raise the possibility that this treatment favors the replacement of $N$. apis by $N$. ceranae, since Fumagillin is more effective against the former.

Higes et al (2008) indicate that infection can be controlled by administering $120 \mathrm{mg}$ of Fumagillin, but reinfection after 6 months cannot be avoided. It should further be noted that the use of Fumagillin is not yet permitted in the majority of the member states of the European Union due to the high concentration of drug residues in the honey (Nozal et al 2008, Porrini et al 2010). A medication needs to be found which does not contaminate the honey, and especially does not affect the health of consumers. In this situation, Porrini et al (2010) suggests the use of bacterial metabolites produced by bacteria such as Bacillus and Entorococcus isolated from the mid intestine of the honey bee and from its honey. One possibility is surfactin (a compound produced by B. subtilis), which significantly suppresses the parasite load and does not damage the health of the bee. There are also a number of metabolites produced by Lactobacillus johnsonii CRL 1647 (mainly organic acids), which have no toxic effects against honey bees, increase the hive population through the administration of lactic acids, and increase the amount of fatty bodies in the bee; this results in a reduction in pathogen intensity after the second application of organic acid treatment, as well as enhancing the effectiveness of Fumagillin (Maggi et al 2013). Nevertheless, further research is still required to determine the minimum and maximum concentrations to avoid leaving residues in the honey that are harmful to human health (Porrini et al 2010). Furthermore, the possibility of sexual reproduction by these microsporidia species has profound implications for the evolution of their virulence, if they broaden their range of hosts and acquire resistance to the drugs through recombination of their genes (Ironside 2013).

Another way of controlling disease is through hive management with the aim of creating unfavorable environmental conditions for the parasite. Following this principle Williams et al (2010) studied the effects of the environment on $N$. ceranae by hibernating a group of hives in controlled conditions as compared to a group in the open air. They concluded that treatment by hibernation does not have a significant effect on the attack intensity $N$. ceranae in the following spring. Huang et al (2012) suggest that it may be possible to select bees which are tolerant to Nosema, and in particular $N$. ceranae; this line of research might contribute to the management and control of this parasite. Furthermore, replacing the queen is vital for maintaining the homeostasis of a Nosema infected colony; it results in a notable reduction in Nosema infection rates, comparable with that induced by treatment with Fumagillin (Botias et al 2012). At present the only recorded treatment for Nosema disease is Fumagillin, which is banned for using in Europe since the maximum residue level has not yet been determined. As a result, prolonged use leads to resistance to the treatment of this disease (Huang et al 2013).

It has been observed that vetiver oil, thymol, resveratrol and lysozyme oil have been considered suitable for treating nosemosis in bees, without causing toxic effects in adults or presenting anti-feeding properties. Bees fed with thymol candy show a progressive decrease in infection levels 19 days after infection, with $6 \%$ lower levels after 13 days and a fall of $68 \%$ between 19 and 25 days (Maistrello et al 2008). Therefore, thymol and resveratrol have potential for the development of alternative strategies for nosemosis control, resulting also in significantly longer-lived honey bees (Maistrello et al 2008, Costa et al 2010). In the case of thymol the longer survival may be related with the lower spore load, while in the case of resveratrol the increased survival may be explained by the antioxidant properties of the substance (Costa et al 2010).

Furthermore, because of the risk that the disease may develop chemical resistance to treatment, new, alternative control methods have been created such as the use of natural phytopharmacological preparations. One example of these is BeeCleanse, a natural preparation containing different herbs, vitamins, minerals and essential acids; its use did not cure the disease but caused a considerable reduction in the number of spores (Tlak et al 2013). Good results have also been observed with a preparation of natural herbs called Nozevit (a natural extract from a particular type of Nothofagus bark, recognised as a rich tannin source). It induces the production and secretion of mucus by the honey bees' epithelial layer, which covers the peritrophic membrane to form a more resistant coating ensuring protection and resistance against a new invasion by Nosema sp. spores. It also prevents spores from germinating (Tlak et al 2011). Other studies have assessed 
the activity of plant extracts in the development of $N$. ceranae, such as etanol extracts obtained from Artemisia absinthium, Allium sativum, Laurus nobilis and Ilex paraguariensis. They show that a $1 \%$ concentration of extract of $L$. nobilis significantly hindered the development of $N$. ceranae, suggesting that the use of natural substances may be put forward as alternative anti-parasite treatment (Porrini et al 2011).

Epidemiological information on Nosema will help to improve disease management practices, implementing new hygiene policies and reducing additional production costs (Razmaraii et al 2013). Since the treatment for Nosema is not available in many countries, there is an urgent need to develop possible treatments or beekeeping techniques to combat the rapid spread of this dangerous emerging disease (Botias et al 2013), helping to improve the natural defense behaviour of the colony through beekeeping practices and reducing the likelihood of colony loss (Dussaubat et al 2013 ${ }^{\mathrm{a}}$ ).

\section{CONCLUSIONS}

$N$. ceranae is a disease that is already causing concern in the scientific world, and is considered to be a threat for the conservation of honey bee populations and the beekeeping industry. Studies have therefore focused on the recognition and description of this parasite, since changes in its feeding habits are affecting not only oriental bees, but also european honey bees and several species of bumblebee. Further studies are needed on the effects of infection in order to provide beekeepers with proper control strategies and combat the rapid spread of this dangerous disease.

The high virulence of this disease, coupled with the weak individual immunity of $A$. mellifera, makes it necessary to give more importance to genetic improvements, with the aim of improving features of collective behaviour. The parasite may very often be present in a hive without causing symptoms of the disease, probably because of the resistance of the bees or the presence of a less virulent strain of the parasite; the latter may result from its high levels of polymorphism and the wide variety of haplotypes in each colony. This would account for the differences reported in parasitism, the symptoms reported in the field and its resistance to treatment.

It must also be considered that when a colony is weakened by $N$. ceranae, it becomes susceptible to other stress factors such as pesticides, other pathogens and malnutrition. The negative synergic effects of these factors significantly reduce bee survival, affecting the hive's immunological system and contributing to the loss of more colonies.

Further investigation is needed on ways of controlling this disease to develop drugs that do not harm the health of either bees or consumers, and do not leave residues in the honey. Possible solutions include the use of bacterial metabolites or oils such as vetiver, thymol or resveratrol; and the use of natural phyto-pharmaceutical preparations based on herbs, vitamins, tannins and essential fatty acids. These have been considered good alternatives for treating nosemosis.

Furthermore, N. ceranae is already present in all the world's continents, and particularly in Chile, implying that this disease is a serious threat. More information is required on its real impact and effect on our bees and commercial farms.

\section{ACKNOWLEDGEMENTS}

The authors would like to acknowledge the support of CONICYT FONDEF Project "Programa IDeA" CA13I10140.

\section{REFERENCES}

Alaux C, J Brunet, C Dussaubat, F Mondet, S Tcamitchan, M Cousin, J Brillard, A Baldy, L Belzunces, Y Le Conte. 2010. Interactions between Nosema microspores and a neonicotinoid weaken honeybees (Apis mellifera). Environ Microbiol 12, 774-782.

Alaux C, M Folschweiller, C McDonnell, D Beslay, M Cousin, C Dussaubat, J Brunet, Y Le Conte. 2011. Pathological effects of the microsporidium Nosema ceranae on honey bee queen physiology (Apis mellifera). J Invertebr Pathol 106, 380-385.

Antúnez K, R Martín-Hernández, L Prieto, A Meana, P Zunino, M Higes. 2009. Immune suppression in the honey bee (Apis mellifera) following infection by Nosema ceranae (Microsporidia). Environ Microbiol 11, 2284-2290.

Aufauvre J, D Biron, C Vidau, R Fontbonne, M Roudel, M Diogon, $B$ Viguès, L Belzunces, F Delbac, N Blot. 2012. Parasite-insecticide interactions: a case study of Nosema ceranae and fipronil synergy on honeybee. Sci Rep 2, 326.

Aufauvre J, B Misme-Aucouturier, B Viguès, C Texier, F Delbac, N Blot. 2014. Transcriptome analyses of the honeybee response to Nosema ceranae and insecticides. PLOS ONE 9, e91686.

Bacandritsos N, A Granato, G Budge, I Papanastasiou, E Roinioti, M Caldon, C Falcaro, A Gallina, F Mutinelli. 2010. Sudden deaths and colony population decline in Greek honey bee colonies. J Invertebr Pathol 105, 335-340.

Bailey L. 1967. Nosema apis and dysentery of the honey bee. J Apicult Res 6, 121-125.

Bailey L, BV Ball. 1991. Honey bee pathology. Academic Press, London, UK.

Boncristiani H, R Underwood, R Schwarz, JD Evans, J Pettis, D vanEngelsdorp. 2012. Direct effect of acaricides on pathogen loads and gene expression levels in honey bees Apis mellifera. J Insect Physiol 58, 613-620.

Botias C, R Martín-Hernández, J Días, P García-Palencia, M Matabuena, A Juarranz, L Barrios, A Meana, A Nanetti, M Higes. 2012. The effect of induced queen replacement on Nosema spp. infection in honey bee (Apis mellifera iberiensis) colonies. Environ Microbiol 44, 845-859.

Botias C, R Martín-Hernández, L Barrios, A Meana, M Higes. 2013. Nosema spp. infection and its negative effects on honey bees (Apis mellifera iberiensis) at the colony level. Vet Res 44, 25.

Bourgeois AL, TE Rinderer, LD Beaman, RG Danka. 2010. Genetic detection and quantification of Nosema apis and Nosema ceranae in the honey bee. J Invertebr Pathol 103, 53-58.

Bradbear N. 2009. Bees and their role in forest livelihoods: a guide to the services provided by bees and the sustainable harvesting, processing and marketing of their products. Food and Agriculture Organization of the United Nations (FAO), Rome, Italy.

Calderón RA, LA Sánchez, O Yáñez, N Fallas. 2008. Presence of Nosema ceranae in Africanized honey bee colonies in Costa Rica. J Apicult Res 47, 328-329. 
Carletto J, P Blanchard, A Gauthier, F Schurr, MP Chauzat, M Ribiere. 2013. Improving molecular discrimination of Nosema apis and Nosema ceranae. J Invertebr Pathol 113, 52-55.

Chaimanee V, N Warrit, P Chantawannakul. 2010. Infections of Nosema ceranae in four different honeybee species. J Invertebr Pathol 105, 207-210.

Chen Y, JD Evans, IB Smith, JS Pettis. 2008. Nosema ceranae is a longpresent and wide-spread microsporidian infection of the European honey bee (Apis mellifera) in the United States. J Invertebr Pathol 97, 186-188.

Chen Y, JD Evans, C Murphy, R Gutell, M Zurker, D Gundensen-Rindal, JS Pettis. 2009a. Morphological, molecular, and phylogenetic characterization of Nosema ceranae, a microsporidian parasite isolated from the European honey bee, Apis mellifera. J Eukaryot Microbiol 56, 142-147.

Chen Y, JD Evans, L Zhou, H Boncristiani, K Kimura, T Xiao, AM Litkowski, JS Pettis. 2009 ${ }^{\text {}}$. Asymmetrical coexistence of Nosema ceranae and Nosema apis in honey bees. J Invertebr Pathol 101, 204-209.

Chen Y, ZY Huang. 2010. Nosema ceranae, a newly identified pathogen of Apis mellifera in the USA and Asia. Apidologie 41, 364-374.

Chen Y, J Pettis, Y Zhao, X Liu, L Tallon, L Sadzewicz, R Li, H Zheng, S Huang, X Zhang, M Hamilton, S Pernal, A Melathopoulos, X Yan, J Evans. 2013. Genome sequencing and comparative genomics of honey bee microsporidia, Nosema apis reveal novel insights into host-parasite interactions. BMC Genomics 14, 451.

Corradi N, H Slamovits. 2010. The intriguing nature of microsporidian genomes. Brief Funct Genomic 10, 115-124.

Costa C, M Lodesani, L Maistrello. 2010. Effect of thymol and resveratrol administered with candy or syrup on the development of Nosema ceranae and on the longevity of honeybees (Apis mellifera L.) in laboratory conditions. Apidologie 41, 141-150.

Desneux N, A Decourtye, JM Delpuech. 2007. The sublethal effects of pesticides on beneficial arthropods. Annu Rev Entomol 52, 81-106.

Dussaubat C, JL Brunet, M Higes, J Colbourne, J Lopez, JH Choi, R Martín-Hernández, C Botias, M Cousin, C McDonnell, M Bonnet, L Belzunces, R Moritz, Y Le Conte, C Alaux. 2012. Gut pathology and responses to the Microsporidium Nosema ceranae in the honey bee Apis mellifera. PLoS ONE 7, e37017.

Dussaubat C, A Maisonnasse, D Crauser, D Beslay, G Costagliola, S Soubeyrand, A Kretzchmarc, Y Le Conte. 2013 ${ }^{\mathrm{a}}$. Flight behavior and pheromone changes associated to Nosema ceranae infection of honey bee workers (Apis mellifera) in field conditions. J Invertebr Pathol 113, 42-51.

Dussaubat C, S Sagastume, T Gómez-Moracho, C Botias, P GarcíaPalencia, R Martín-Hernández, Y Le Conte, M Higes. 2013 ${ }^{\text {b }}$ Comparative study of Nosema ceranae (Microsporidia) isolates from two different geographic origins. Vet Microbiol 162, 670-678.

Ellis JD, JD Evans, J Pettis. 2010. Colony losses, managed colony population decline, and colony collapse disorder in the United States. J Apicult Res 49, 134-136.

Fernández J, F Puerta, M Cousinou, F Dios-Palomares, F Campano, L Redondo. 2012. Asymptomatic presence of Nosema spp. in Spanish commercial apiaries. J Invert Pathol 111, 106-110.

Fries I, F Feng, A da Silva, SB Slemenda, NJ Pieniazek. 1996. Nosema ceranae n. Sp. (Microspora, Nosematidae), morphological and molecular characterization of a microsporidian parasite of the Asian honey bee Apis cerana (Hymenoptera, Apidae). Europ J Protistol 32, 356-365.

Fuentealba J, P Linero. 2010. Informe de caso de Nosema ceranae en la Región del Bío Bío 2009. Servicio Agrícola y Ganadero (SAG), Santiago, Chile.

Garrido PM, K Antúnez, M Martín, MP Porrini, P Zunino, MJ Eguaras 2013. Immune-related gene expression in nurse honey bees (Apis mellifera) exposed to synthetic acaricides. J Insect Physiol 59, 113-119.

Genersch E. 2010. Honey bee pathology: current threats to honey bees and beekeeping. Appl Microbiol Biot 87, 87-97.
Giersch T, T Berg, F Galea, M Hornitzky. 2009. Nosema ceranae infects honey bees (Apis mellifera) and contaminates honey in Australia. Apidologie 40, 117-123.

Gisder S, N Möckel, A Linde, E Genersch. 2010. A cell culture model for Nosema ceranae and Nosema apis allows new insights into the life cycle of these important honey bee-pathogenic microsporidia. Environ Microbiol 13, 404-413.

Gisder S, E Genersch. 2013. Molecular differentiation of Nosema apis and Nosema ceranae based on species-specific sequence differences in a protein coding gene. J Invertebr Pathol 113, 1-6.

Gómez-Moracho T, X Maside, R Martín-Hernández, M Higes, C Bartolomé. 2014. High levels of genetic diversity in Nosema ceranae within Apis mellifera colonies. Parasitol 141, 475-481.

Graystock P, K Yates, B Darvill, D Goulson, W Hughes. 2013. Emerging dangers: deadly effects of an emergent parasite in a new pollinator host. J Invert Pathol 114, 114-119.

Higes M, R Martín-Hernández, A Meana. 2006. Nosema ceranae, a new microsporidian parasite in honeybees in Europe. $J$ Invertebr Pathol 92, 93-95.

Higes M, P García-Palencia, R Martín-Hernández, A Meana. 2007. Experimental infection of Apis mellifera honeybees with Nosema ceranae (Microsporidia). J Invertebr Pathol 94, 211-217.

Higes M, R Martín-Hernández, C Botias, E Garrido-Bailón, AV González-Porto, L Barrios, MJ del Nozal, JL Bernal, JJ Jiménez, P García-Palencia, A Meana. 2008. How natural infection by Nosema ceranae causes honeybee colony collapse. Environ Microbiol 10, 2659-2669.

Higes M, R Martín-Hernández, E Garrido-Bailón, AV González-Porto, P García-Palencia, A Meana, MJ del Nozal, R Mayo, JL Bernal. 2009a. Honeybee colony collapse due to Nosema ceranae in professional apiaries. Environ Microbiol Rep 1, 110-113.

Higes M, R Martín-Hernández, E Garrido-Bailón, C Botias, A Meana. $2009^{\mathrm{b}}$. First detection of Nosema ceranae (Microsporidia) in African honey bees (Apis mellifera intermissa). J Apicult Res 48, 217-219.

Higes M, R Martín-Hernández, P García-Palencia, P Marín, A Meana. $2009^{c}$. Horizontal transmission of Nosema ceranae (Microsporidia) from worker honeybees to queens (Apis mellifera). Environ Microbiol Rep 1, 495-498.

Higes M, P García-Palencia, C Botias, A Meana, R Martín-Hernández. $2010^{\text {a }}$. The differential development of microsporidia infecting worker honey bee (Apis mellifera) at increasing incubation temperature. Environ Microbiol Rep 2, 745-748.

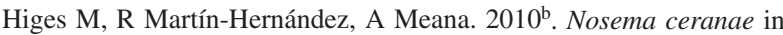
Europe: an emergent type C nosemosis. Apidologie 41, 375-392.

Higes M, R Martín-Hernández, A Martínez-Salvador, E Garrido-Bailón, A Meana, JL Bernal, MJ del Nozal, J Bernal. 2010 . A preliminary study of the epidemiological factors related to honey bee colony loss in Spain. Environ Microbiol Rep 2, 243-250.

Higes M, A Juarranz, J Dias-Almeida, S Lucena, C Botias, A Meana, P García-Palencia, R Martín-Hernández. 2013. Apoptosis in the pathogenesis of Nosema ceranae (Microsporidia: Nosematidae) in honey bees (Apis mellifera). Environ Microbiol Reps 5, 530-536.

Hinojosa A, D González. 2004. Prevalencia de parásitos en Apis mellifera L. en colmenares del secano costero e interior de la VI Región, Chile. Parasitol Latinoam 59, 137-141.

Holt H, K Aronstein, C Grozinger. 2013. Chronic parasitization by Nosema microsporidia causes global expression changes in core nutritional, metabolic and behavioral pathways in honey bee workers (Apis mellifera). BMC Genomics 14, 799.

Huaiquil S, G Sepúlveda, R Rebolledo. 2009. Sanidad apícola en el Valle de Azapa, Región de Arica y Parinacota, Chile. Idesia 27, 71-78.

Huang Q, P Kryger, Y Le Conte, R Morits. 2012. Survival and immune response of drones of a Nosemosis tolerant honey bee strain towards N. ceranae infections. J Invertebr Pathol 109, 297-302.

Huang W, L Solter. 2013. Comparative development and tissue tropism of Nosema apis and Nosema ceranae. J Invertebr Pathol 113, 35-41. 
Huang W, L Solter, P Yau, B Imai. 2013. Nosema ceranae escapes fumagillin control in honey bees. PLoS Pathog 9, e1003185.

Invernizzi C, C Abud, IH Tomasco, J Harriet, G Ramallo, J Campá, H Katz, G Gardiol, Y Mendoza. 2009. Presence of Nosema ceranae in honey bees (Apis mellifera) in Uruguay. J Invertebr Pathol 101, 150-153.

Ironside JE. 2013. Diversity and recombination of dispersed ribosomal DNA and protein coding genes in Microsporidia. PLOS ONE 8, e55878.

Klee J, AM Besana, E Genersch, S Gisder, A Nanetti, D Quyet, T Xuan, F Puerta, JM Ruz, P Kryger, D Message, F Hatjina, S Korpela, I Fries, RJ Paxton. 2007. Widespread dispersal of the microsporidian Nosema ceranae, an emergent pathogen of the western honey bee, Apis mellifera. J Invertebr Pathol 96, 1-10.

Li J, W Chen, J Wu, W Peng, J An, P Schmid-Hempel, R Schmid-Hempel. 2012. Diversity of Nosema associated with bumblebees (Bombus spp.) from China. Int J Parasitol 42, 49-61.

Liu F, Q Wang, PL Dai, YY Wu, HK Song, T Zhou. 2008. Natural stripe of Microsporidia of honeybee in China. Chinese Bull Entomol 45, 963-966.

Maggi M, P Negri, S Plischuk, N Szawarski, F De Piano, L De Feudis, M Eguaras, C Audisio. 2013. Effects of the organic acids produced by a lactic acid bacterium in Apis mellifera colony development, Nosema ceranae control and fumagillin efficiency. Vet Microbiol 167, 474-483.

Maistrello L, M Lodesani, C Costa, F Leonardi, G Marani, M Caldon, F Mutinelli, A Granato. 2008. Screening of natural compounds for the control of nosema disease in honeybees (Apis mellifera). Apidologie 39, 436-445.

Manzoor M, V Mathivanan, GH Nabi, GM Mir, S Sabhanayakam. 2013. Nosemosis and its effect on performance of honey bees-a review. Int J Pharm Bio Sci 4, 923-937.

Martín-Hernández R, A Meana, L Prieto, A Martínez, E Garrido-Bailón, M Higes. 2007. Outcome of colonization of Apis mellifera by Nosema ceranae. Appl Environ Microbiol 73, 6331-6338.

Martínez J, G Leal, P Conget. 2012. Nosema ceranae an emergent pathogen of Apis mellifera in Chile. Parasitol Res 111, 601-607.

Mayack C, D Naug. 2009. Energetic stress in the honeybee Apis mellifera from Nosema ceranae infection. J Invertebr Pathol 100, 185-188.

Mayack C, D Naug. 2010. Parasitic infection leads to decline in hemolymph sugar levels in honeybee foragers. J Insect Physiol $56,1572-1575$

Medici SK, GE Sarlo, PM Porrini, BM Braunstein, MJ Eguaras. 2012. Genetic variation and widespread dispersal of Nosema ceranae in Apis mellifera apiaries from Argentina. Parasitol Res 110, 859-864.

Naug D, A Gibbs. 2009. Behavioral changes mediated by hunger in honeybees infected with Nosema ceranae. Apidologie 40, 595-599.

Nozal M, JL Bernal, MT Martín, J Bernal, A Álvaro, R Martín, M Higes. 2008. Trace analysis of fumagillin in honey by liquid chromatographydiode array-electrospray ionization mass spectrometry. A $J$ Chromatogr 1190, 224-231.

O'Mahony EM, WT Tay, RJ Paxton. 2007. Multiple rRNA variants in a single spore of the microsporidium Nosema bombi. J Eukar Microbiol 54, 103-109.

Paxton RJ. 2010. Does infection by Nosema ceranae cause "Colony Collapse Disorder" in honey bees (Apis mellifera)?. J Apicult Res 49, 80-84

Plischuk S, R Martín-Hernández, L Prieto, M Lucía, C Botias, A Meana, AH Abrahamovich, C Lange, M Higes. 2009. South American native bumblebees (Hymenoptera: Apidae) infected by Nosema ceranae (Microsporidia), an emerging pathogen of honeybees (Apis mellifera). Environ Microbiol Rep 1, 131-135.

Ponton F, K Wilson, SC Cotter, D Raubenheimer, SJ Simpson. 2011. Nutritional immunology: a multi-dimensional approach. PLoS Pathog 7, e1002223.

Porrini MP, MC Audisio, DC Sabaté, C Ibarguren, SK Medici, EG Sarlo, PM Garrido, MJ Eguaras. 2010. Effect of bacterial metabolites on microsporidian Nosema ceranae and on its host Apis mellifera. Parasitol Res 107, 381-388.

Porrini MP, NJ Fernández, P Garrido, L Gende, S Medici, J Eguaras. 2011. In vivo evaluation of antiparasitic activity of plant extracts on Nosema ceranae (Microsporidia). Apidologie 42, 700-707.

Potts S, S Roberts, R Dean, G Marris, M Brown, R Jones, P Neuman, J Settele. 2010. Declines of managed honey bees and beekeepers in Europe. J Apicult Res 49, 15-22.

Razmaraii N, S Sadegh-Eteghad, H Babaei, H Paykari, K Esmaeilnia, L Froghy. 2013. Molecular identification of Nosema species in East-Azerbaijan province, Iran. Arch Razi Inst 68, 23-27.

Retschnig G, P Neumann, G Williams. 2014. Thiacloprid-Nosema ceranae interactions in honey bees: Host survivorship but not parasite reproduction is dependent on pesticide dose. J Invert Pathol 118, 18-19.

Rodríguez M, M Vargas, M Gerding, H Navarro, K Antúnez. 2012. Viral infection and Nosema ceranae in honey bees (Apis mellifera) in Chile. J Apicult Res 51, 285-287.

Rodríguez M, M Vargas, K Antúnez, M Gerding, F Ovídio, N Zapata. 2014. Prevalence and phylogenetic analysis of honey bee viruses in the Biobío Region of Chile and their association with other honey bee pathogens. Chilean J Agric Res 74, 170-177.

Roudel M, J Aufauvre, B Corbara, F Delbac, N Blot. 2013. New insights on the genetic diversity of the honeybee parasite Nosema ceranae based on multilocus sequence analysis. Parasiltol 140, 1346-1356.

Shafer ABA, GR Williams, D Shutler, REL Rogers, DT Stewart. 2009. Cophylogeny of Nosema (Microsporidia: Nosematidae) and bees (Hymenoptera:Apidae) suggests both cospeciation and a host switch. J Parasitol 95, 198-203.

Smith ML. 2012. The honey bee parasite Nosema ceranae: transmissible via food exchange? PLOS ONE 7, e43319.

Stevanovic J, Z Stanimirovic, E Genersch, SR Kovacevic, J Ljubenkovic, M Radakovic, N Aleksic. 2011. Dominance of Nosema ceranae in honey bees in the Balkan countries in the absence of symptoms of colony collapse disorder. Apidologie 42, 49-58.

Teixeira EW, L Guimaraes dos Santos, A Sattler, D Message, M Teles, M Fonseca, M Lopes, T Francoy. 2013. Nosema ceranae has been present in Brazil for more than three decades infecting Africanized honey bees. J Invert Pathol 114, 250-254.

Tlak I, Z Kozaric, D Berta, S Nejedli, Z Petrinec. 2011. Effect of the herbal preparation Nozevit on the mid-gut structure of honeybees (Apis mellifera) infected with Nosema sp. spores. Veterinarni Medicina 56, 344-351.

Tlak I, Z Tomljanovic, LJ Stanisavljevic. 2013. An environmentally friendly approach to the control of Varroa destructor mite and Nosema ceranae disease in Carniolan honeybee (Apis mellifera carnica) colonies. Arch Biol Sci Belgrade 65, 1585-1592.

Traver BE, RD Fell. 2011. Nosema ceranae in drone honey bees (Apis mellifera). J Invertebr Pathol 107, 234-236.

Vandame R, MA Palacio. 2010. Preserved honey bee health in Latin America: A fragile equilibrium due to low-intensity agriculture and beekeeping? Apidologie 41, 243-255.

Van der Zee R, T Gómez-Moracho, L Pisa, S Sagastume, P GarcíaPalencia, X Maside, C Bartolomé, R Martín-Hernández, M Higes. 2014. Virulence and polar tube protein genetic diversity of Nosema ceranae (Microsporidia) field isolates from Northern and Southern Europe in honeybees (Apis mellifera iberiensis). Environ Microbiol Rep 6, 401-413.

VanEngelsdorp D, JD Evans, C Saegerman, C Mullin, E Haubruge, BK Nguyen, M Frazier, J Frazier, D Cox-Foster, Y Chen, R Underwood, DR Tarpy, JS Pettis. 2009. Colony collapse disorder: a descriptive study. PLoS One 4, e6481-e6497.

VanEngelsdorp D, J Hayes, R Underwood, J Pettis. 2010. A survey of honey bee colony losses in the United States, fall 2008 to spring 2009. J Apicult Res 49, 7-14.

Vidau C, M Diogon, J Aufauvre, R Fontbonne, B Viguès, JL Brunet, C Texier, DG Biron, N Blot, H El Alaoui, LP Belzunces, F Delbac. 2011. Exposure to sublethal doses of fipronil and thiacloprid highly 
increases mortality of honeybees previously infected by Nosema ceranae. PLoS ONE 6, e21550.

Whitaker J, AL Szalanki, M Kence. 2011. Molecular detection of Nosema ceranae and N. apis from Turkish honey bees. Apidologie 42, 174-180.

Williams GR, ABA Shafer, REL Rogers, D Shutler, DT Stewart. 2008. First detection of Nosema ceranae, a microsporidian parasite of European honey bees (Apis mellifera), in Canada and central USA. J Invertebr Pathol 97, 189-192.

Williams GR, MA Sampson, D Shutler, REL Rogers. $2008^{\mathrm{b}}$. Does fumagillin control the recently detected invasive parasite Nosema ceranae in western honey bees (Apis mellifera)? J Invertebr Pathol 99, 342-344.

Williams BAP. 2009. Unique physiology of host-parasite interactions in microsporidia infections. Cell Microbiol 11, 1551-1560.
Williams GR, D Shutler, REL Rogers. 2010. Effects at Neartic northtemperate latitudes of indoor versus outdoor overwintering on the microsporidium Nosema ceranae and western honey bees (Apis mellifera). J Invertebr Pathol 104, 4-7.

Williams GR, D Shutler, C Little, K Burgher-MacLellan, R Rogers. 2011. The microsporidian Nosema ceranae, the antibiotic Fumagilin-B®, and western honey bee (Apis mellifera) colony strength. Apidologie, $42,15-22$.

Wittner M, LM Weiss. 1999. The microsporidia and microsporidiosis. ASM Press, Washington, DC, USA.

Yoshiyama M, K Kimura. 2011. Distribution of Nosema ceranae in the European honeybee, Apis mellifera in Japan. J Invertebr Pathol $106,263-267$ 